\title{
Analgesic and toxicological evaluation of the stem bark of Albizia zygia Benth (Mimosoideae).
}

\author{
Tavs A. Abere ${ }^{1}$, Profit Ibanishuka ${ }^{2}$, Rose I. Jesuorobo ${ }^{3}$ \\ ${ }^{1,3}$ Department of Pharmacognosy, Faculty of Pharmacy, University of Benin, Benin City, PMB 1154, Nigeria \\ ${ }^{2}$ Department of Pharmacy, University of Benin Teaching Hospital, Benin City, PMB 1154, Nigeria.
}

\begin{abstract}
:
Background: Albizia zygia Benth is used in ethnomedicine in West Africa for the management of painful conditions associated with tropical diseases. In the present study, the analgesic activity as well as the toxicological profile of the aqueous methanol stem bark extract was evaluated to confirm traditional usage and justify continuous usage.

Method: The analgesic activity was evaluated using acetic acid-induced writhing response and hot plate model in Swiss albino mice. Acute toxicological evaluation was carried out in mice while 28-day assessment was done in rats.

Results: Phytochemical screening revealed the presence of alkaloids, tannins, saponins, flavonoids and cardiac glycosides. The aqueous methanol extract $\left(20-80 \mathrm{mgkg}^{-1}\right.$ body weight) significantly $(p<0.01)$ inhibited acetic acid-induced abdominal constriction and also significantly $(p<0.05)$ prolonged the reaction latency to pain thermally-induced in mice by the hot plate. The activity of the extract at $80 \mathrm{mgkg}^{-1}$ was comparable to the reference standards Aspirin (Acetic acid-induced writhing) and Morphine (Hot plate model). Oral doses as high as $5 \mathrm{gkg}^{-1}$ did not cause death or toxicological symptoms in mice. There were no marked adverse alterations or degeneration of tissues of the major organs during acute toxicity test.

Conclusion: The present study indicates that the stem back of A. zygia possesses analgesic properties which lend credence to its use in ethnomedicine in the treatment of waist pain, arthritis, sprains and in feverish conditions, but its overall safety profile needs to be further evaluated.
\end{abstract}

Keywords: Albizia zygia; analgesic; writhing; toxicological profile.

\section{Introduction}

Albizia zygia Benth belongs to the Mimosoideae family, one of the three subfamilies of Leguminosae. It is a deciduous tree $9-30 \mathrm{~m}$ tall with a spreading crown and graceful architectural form. Its leaves are pinnate and broadening towards the apex. Flowers are subsessile and calyx is puberulous, white or pink in colour. The seeds are smaller and flatter compared to seeds of other Albizia species, but have the characteristic round shape, with a slightly swollen [1].

A. zygia, commonly known as red nango in English, Ayinre-weere (Yoruba) and Nyie-avu (Igbo) is mainly used in ethnomedicine for the treatment of fever and waist pain [2]. Extracts have been shown to be molluscicidal and the roots have been reported to be used in the treatment of tuberculosis in Lake Victoria region in Kenya. The methanol extract of the stem bark has been shown to have in-vitro antitrypanosomal activity against Trypanosoma brucei [3]. Also, when the cytotoxic effects of some selected Camerounian plants with efficacy against $T$. cruzi and $T$. brucei rhodesiense were evaluated, cytotoxicity and selectivity index was high with the methanol extract of A. zygia.

Traditional plant medicines including preparations from A. zygia are used throughout Africa in the treatment of malaria and trypanosomiasis. Although, a number of research studies have been carried out on this plant, there is no scientific evidence on the analgesic activity of A. zygia. Scientific evaluation of toxicity by determining lethal dose (LD 50) and sub-acute toxicity effects on major organs will aid its continous usage. The present study was designed to investigate A. zygia for its analgesic activity as well as establish its toxicological profile

\section{Preparation of plant extract}

\section{Materials and Methods}

The stem barks of Albizia zygia Benth (Mimosoideae) were collected in Ugbowo area of Benin City, Edo State, Nigeria. The plants were authenticated by the curator at the Department of Pharmacognosy Herbarium, University of Benin, Benin City, where voucher specimens were deposited. The stem barks were air-dried for 7 days. Further drying was carried out in the oven at $40{ }^{\circ} \mathrm{C}$ for $8 \mathrm{~h}$, crushed with a mortar and pistle and powdered using an electric mill. The powder was extracted with $50 \%$ aqueous methanol and concentrated in vacuo. 
Animals

Swiss albino mice of both sexes $(25.67 \pm 1.44 \mathrm{~g})$ and male Wistar rats $(220.00 \pm 13.85 \mathrm{~g})$ were obtained from the Animal House, Department of Pharmacology and Toxicology, Faculty of Pharmacy, University of Benin, Benin City. All the animals were kept under standard environmental conditions and were handled according to international protocol for use of animals in experiments [4]. They were fed with standard pellets and tap water ad libitum. Ethical approval for the study was obtained from the College of Medicine, University of Benin Animal Ethics Committee (ADM/F. 22A/Vol. viii/349).

\section{Phytochemical studies}

Screening for secondary plant metabolites was carried out according to previously described methods [5-8]. These include chemical tests for tannins, alkaloids, cardiac, saponin, anthracene and cyanogenetic glycosides.

\section{Analgesic evaluation}

\section{Acetic acid-induced writhing reflex test}

The method of Koster et al, modified by Dambisya and Lee [9] was used. Swiss albino mice of both sexes, fasted for $12 \mathrm{~h}$ were randomly divided into 5 groups of 6 mice per group. Oral doses of 20, 40 and 80 $\mathrm{mgkg}^{-1}$ of the extract and $10 \mathrm{mgkg}^{-1}$ Aspirin prepared in normal saline were administered respectively to the groups of fasted mice. Animals in the control group received only the vehicle $\left(10 \mathrm{mgkg}^{-1}\right)$. One hour after administration, $0.6 \%$ acetic acid $\left(10 \mathrm{mgkg}^{-1}\right)$ was given intraperitoneally to all the mice to induce pain characterized by abdominal constrictions and writhes. The number of writhes observed in each mouse for 30 mins after 5 mins latency was counted and recorded. The percentage protection against abdominal writhing was used to assess the degree of analgesia.

\section{Hot plate model}

The method of Shethy and Anika as modified by Franzotti et al [10] was used. Albino mice of both sexes fasted for $12 \mathrm{~h}$ were randomly divided into 5 groups of 6 per group. Each of the mice was placed on a hot plate maintained at a temperature of $55 \pm 1{ }^{\circ} \mathrm{C}$ and the pain reaction time (PRT) or latency period, which represents the time taken for the mice to react to the pain stimulus, was recorded with a stop watch. The responses to pain stimulus considered included: jumping, raising and licking of hind foot. The cut off point was fixed for 20 seconds. Oral doses of 20, 40 and $80 \mathrm{mgkg}^{-1}$ of the extract and $4 \mathrm{mgkg}^{-1}$ Morphine prepared in normal saline were administered respectively to the group of fasted mice. Animals in the control group received only the vehicle $\left(10 \mathrm{mgkg}^{-1}\right)$.

\section{Toxicological evaluation}

Swiss albino mice (5 animals per group) were orally administered the extract at doses of 1, 2, 3, 4 and 5 $\mathrm{gkg}^{-1}$. The control group received only the vehicle (normal saline $5 \mathrm{mlkg}^{-1}$ ). Each group of mice was placed in the test cage for a 30-min habituation period before drug administration. The animals were observed for $10 \mathrm{~min}$ for the first $6 \mathrm{~h}$ and $10 \mathrm{~min}$ each day for the next two days. Lethality and gross toxicological features (convulsion, diarrhea, hyperactivity and pile-erection) were recorded for each group [11]. The animals were further observed for twenty eight days.

Thirty male Wistar rats were randomly distributed into three groups of ten rats each. The first (A) group served as control and received $5 \mathrm{mlkg}^{-1}$ of normal saline (vehicle) while the second (B) and third (C) groups received oral doses of 250 and $500 \mathrm{mgkg}^{-1}$ per day of the extract respectively for 28 consecutive days. The animals were observed for signs of toxicity (abnormal behaviours, writhing, convulsion, mood, motor activity and general body conditions) for $30 \mathrm{~min}$ each day. At the end of 28 days, the rats were sacrificed under chloroform anesthesia. The livers, kidneys, hearts and spleens were removed and preserved in $10 \%$ formaldehyde solution. Each organ was sectioned (6 $\mu$ thick) embedded in paraffin wax and stained with hematoxylin and eosin [12].

\section{Statistical analysis}

Data are expressed as mean \pm SEM and " $n$ " represents the number of mice used. The differences between the means were analyzed using one way analysis of variance (ANOVA). Values of P $<0.05$ were taken to imply statistical significance between compared data.

\section{Phytochemical screening}

\section{Results}

The results of preliminary phytochemical screening of the stem bark of A. zygia revealed the presence of alkaloids, tannins, flavonoids saponins, cardiac glycosides (Table 1). 


\section{Analgesic effects}

Albizia zygia stem bark extract significantly $(\mathrm{p}<0.001)$ decreased the mean number of abdominal constrictions/writhes in a dose-dependent manner. The percentage inhibition of abdominal constriction was highest at $78.26 \%$ (80 mgkg ${ }^{-1}$ of A. zygia) compared to the positive control, Aspirin $10 \mathrm{mgkg}^{-1}$ with $72.39 \%$ (Table 2). In comparing pain reaction time (PRT) at the pre and post treatment, the extract at the doses of 20, 40 and $80 \mathrm{mgkg}^{-1}$ increased the PRT in a dose-dependent manner (Table 3).

\section{Toxicological evaluation}

In the acute toxicity study, the aqueous ethanol extract of stem bark of A. zygia did not produce any mortality up to the oral dose level of $5 \mathrm{gkg}^{-1}$ body weight in mice. There were no significant changes in behaviour, posture, nature and frequency of stooling, mood and motor activity. The animals did not convulse nor exhibited writhings.

Daily administration of the crude extract did not produce gross toxicological symptoms nor deaths before the Wistar rats were sacrificed after 28 days treatment. General histopathological analysis of the heart (Fig. 1) in the $250 \mathrm{mgkg}^{-1}$ A. zygia treated group showed mild vascular congestion, transmural oedema and mild chronic inflammatory infiltrates. In the liver (Fig. 3), the effects were more of mild congestion in the portal vessels. The spleen showed mild activation of the lymphoid follicles (Fig. 5) while the kidney showed mild interstitial congestion (Fig. 7). There were no significant changes in the histopathological analysis when the dose was increased to $500 \mathrm{mgkg}^{-1}$ (Figs. 2, 4, $6 \&$ \&) compared to when the dose of $250 \mathrm{mgkg}^{-1} \mathrm{was}$ administration.

$\begin{array}{lr}\begin{array}{l}\text { Table 1: Phytochemical constituents of } A . \text { zygia stem bark } \\ \text { Classes of secondary metabolites }\end{array} \\ \text { Inference } \\ \text { Alkaloids } & + \\ \text { Tannins } & + \\ \text { Flavonoids } & + \\ \text { Anthracene derivatives } & - \\ \text { Saponin glycosides } & + \\ \text { Cardiac glycosides } & + \\ \text { Cyanogenetic glycosides } & - \\ \text { Key: } & \\ -\quad=\text { absent; }+ \text { - present } & \end{array}$

Table 2: \%age inhibition of the aqueous methanol stem bark extract of A. zygia on Acetic acid writhing in mice

\begin{tabular}{|c|c|c|c|c|}
\hline Treatment & Dose $\mathrm{mg} / \mathrm{kg}$ & Mean no of writhings & \% inhibition & $\mathrm{p}$-value \\
\hline Normal saline & 10 & $92 \pm 7.68$ & - & - \\
\hline Aspirin & 10 & $25 \pm 2.87$ & 73.39 & $\mathrm{p}<0.001$ \\
\hline A. Zygia & 20 & $48 \pm 11.31$ & 48.26 & $\mathrm{p}<0.001$ \\
\hline A. Zygia & 40 & $38 \pm 4.58$ & 57.83 & $\mathrm{p}<0.001$ \\
\hline A. Zygia & 80 & $20 \pm 4.73$ & 78.26 & $\mathrm{p}<0.001$ \\
\hline
\end{tabular}

Table 3: Effect of aqueous methanol stem bark extract of $A$. zygia on reaction time in mice

\begin{tabular}{|c|c|c|c|c|c|}
\hline Treatment & Dose $\mathrm{mg} / \mathrm{kg}$ & $30 \mathrm{mins}$ & $60 \mathrm{mins}$ & $90 \mathrm{mins}$ & $120 \mathrm{mins}$ \\
\hline Normal saline & 10 & $0.44 \pm 0.18$ & $0.72 \pm 0.18$ & $0.52 \pm 0.06$ & $0.90 \pm 0.33$ \\
\hline Morphine & 4 & $4.28 \pm 0.52^{\mathrm{ns}}$ & $6.10 \pm 1.07^{\mathrm{ns}}$ & $3.32 \pm 0.83^{\text {ns }}$ & $2.90 \pm 0.36^{\text {ns }}$ \\
\hline A. zygia & 20 & $2.16 \pm 0.15^{\text {ns }}$ & $2.46 \pm 0.58^{\text {ns }}$ & $1.56 \pm 0.48^{\text {ns }}$ & $0.92 \pm 0.36^{\text {ns }}$ \\
\hline A. Zygia & 40 & $2.00 \pm 0.47^{\mathrm{a}}$ & $2.78 \pm 0.58^{\mathrm{a}}$ & $2.46 \pm 0.38^{\mathrm{a}}$ & $2.88 \pm 0.25^{\mathrm{a}}$ \\
\hline A. Zygia & 80 & $4.54 \pm 0.48^{\mathrm{a}}$ & $8.12 \pm 1.80^{\mathrm{a}}$ & $3.44 \pm 0.18^{\mathrm{a}}$ & $3.78 \pm 0.61^{\mathrm{a}}$ \\
\hline
\end{tabular}

$\mathrm{a}=\mathrm{p}<0.05$ (Significant); $\mathrm{ns}=$ Not significant

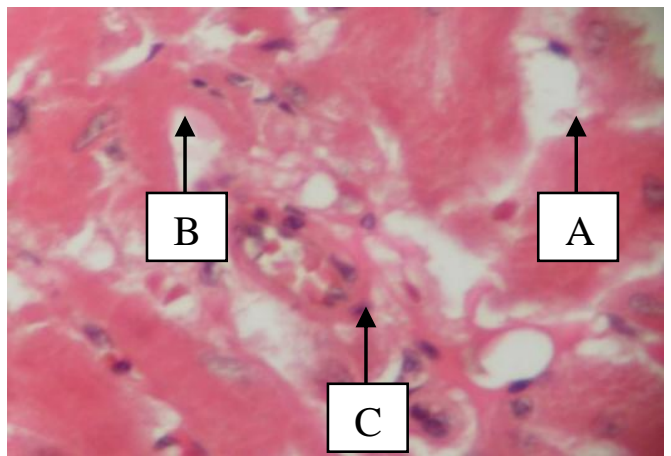

Fig 1: Photomicrograph of the heart of rats administered with $250 \mathrm{mg} / \mathrm{kg}$ of $A$. zygia for 28 days showing mild transmural oedema $\{\mathrm{A}\}$, mild vascular congestion and hypertrophy $\{\mathrm{B}\}$ and mild infiltrate of chronic inflammatory cells $\{C\}(H \& E x$ x $)$ 


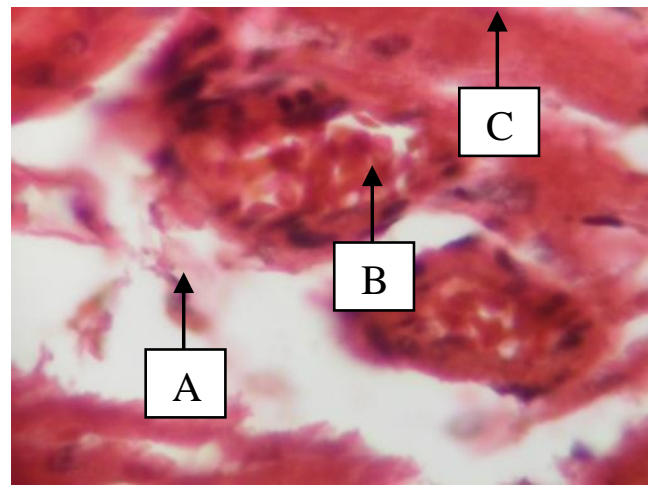

Fig 2: Photomicrograph of the heart of rats administered with $500 \mathrm{mg} / \mathrm{kg}$ of A. zygia for 28 days showing mild transmural oedema $\{A\}$, mild vascular congestion and hypertrophy $\{B\}$ and mild infiltrate of chronic inflammatory cells $\{C\}$ (H\&E x 40)

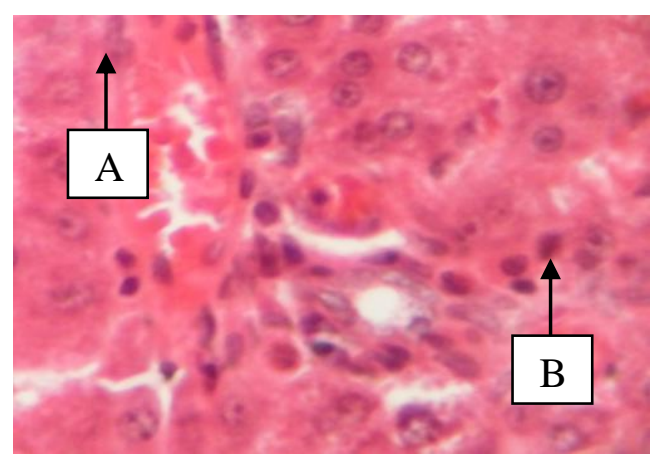

Fig 3: Photomicrograph of the liver of rats administered with $250 \mathrm{mg} / \mathrm{kg}$ of A. zygia for 28 days showing mild portal vascular congestion $\{A\}$ and mild infiltrate of chronic inflammatory cells $\{B\}$ (H\&E x 40)

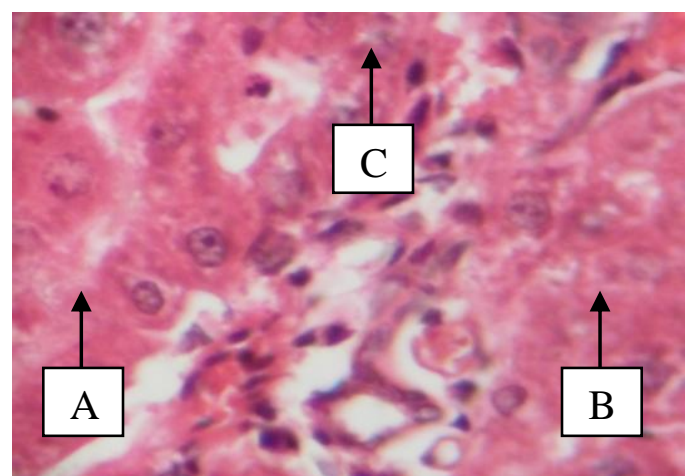

Fig 4: Photomicrograph of the liver of rats administered with $500 \mathrm{mg} / \mathrm{kg}$ of A. zygia for 28 days showing vascular congestion and degeneration $\{A\}$, mild periportal oedema $\{B\}$ and mild infiltrates of chronic inflammatory cells $\{\mathrm{C}\}(\mathrm{H} \& \mathrm{E} x \mathrm{40})$

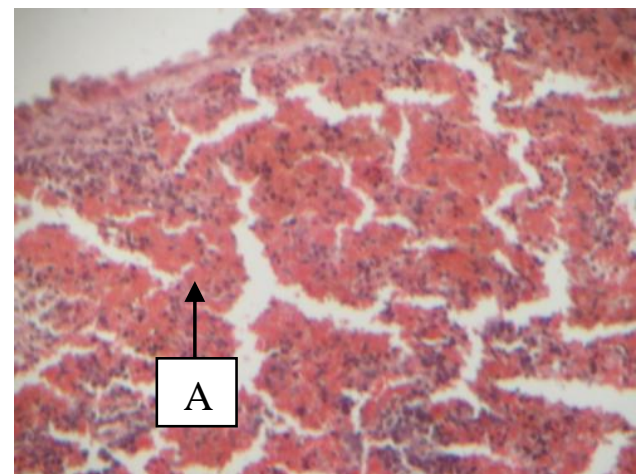

Fig 5: Photomicrograph of the spleen of rats administered with $250 \mathrm{mg} / \mathrm{kg}$ of A. zygia for 28 days showing mild stromal oedema $\{\mathrm{A}\}(\mathrm{H} \& \mathrm{E} \times 10)$ 


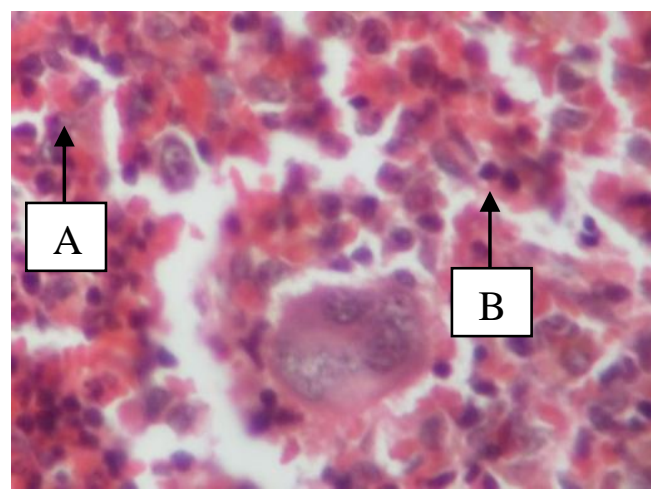

Fig 6: Photomicrograph of the spleen of rats administered with $500 \mathrm{mg} / \mathrm{kg}$ of A. zygia for 28 days showing mild stromal oedema $\{\mathrm{A}\}$ and moderate hyperplasia of sinus histiocytes $\{\mathrm{B}\}$ (H\&E x 40)

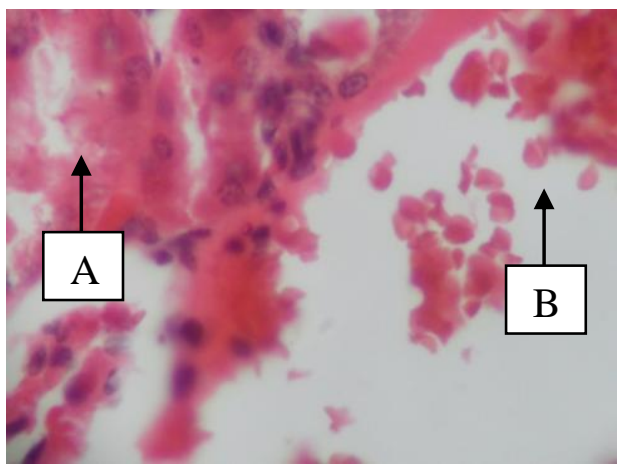

Fig 7: Photomicrograph of the kidney of rats administered with $250 \mathrm{mg} / \mathrm{kg}$ of A. zygia for 28 days showing mild interstitial oedema $\{\mathrm{A}\}$ and vascular congestion and dilatation $\{\mathrm{B}\}(\mathrm{H} \& \mathrm{E} \times 40)$

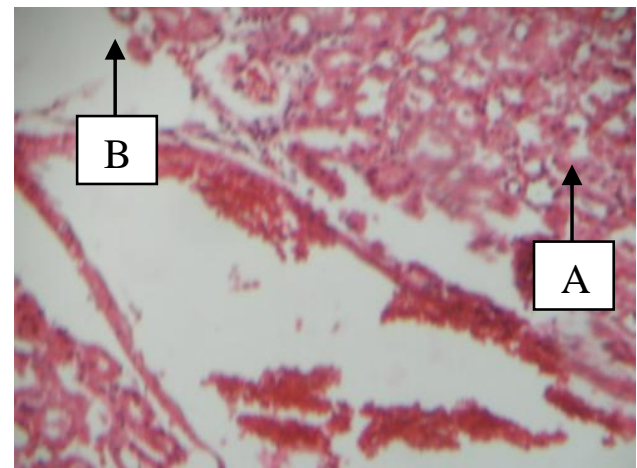

Fig 8: Photomicrograph of the kidney of rats administered with $500 \mathrm{mg} / \mathrm{kg}$ of A. zygia for 28 days showing mild interstitial oedema $\{\mathrm{A}\}$ and vascular congestion and dilatation $\{\mathrm{B}\}(\mathrm{H} \& \mathrm{E} \times 10)$

\section{Discussion}

Phytochemical screening revealed the presence of alkaloids, tannins, flavonoids, saponins and cardiac glycosides. Flavonoids and tannins have been found to possess analgesic and/or anti-inflammatory activities [13]. Prostaglandins, a group of powerful pro-inflammatory signaling molecules have been proven to be potently inhibited by flavonoids [14].

Two anti-nociceptive models (acetic acid-induced writhing reflex and hot plate) were used to evaluate the analgesic activity of Albizia zygia, since tests for analgesic drugs commonly measure nociception and it involves the reaction of animals to pain stimulus [15]. The stimulus may be thermal (tail immersion or hot plate tests), chemical (acetic acid-induced writhing or formalin tests) or mechanical (tail or paw pressure tests).

Acetic acid-induced writhing reflex is a model of visceral pain which is highly useful for screening analgesic drugs [16] and several chemicals such as phenylquinine and acetic acid could induce writhing reflex in laboratory animals. Acetic acid produces writhing reflex in animals by activating the chemo sensitive nociceptors [17]. Also, the level of analgesia in acetic acid-induced models is indicated by the percent reduction in the number of abdominal constrictions [18]. In our study, intraperitoneal (injection of $0.6 \%$ acetic acid) produced abdominal writhing. A. zygia significantly $(\mathrm{p}<0.001)$ decreased the mean number of abdominal 
constriction in a dose-dependent manner. The results indicated that the aqueous methanol extract compared favourably with the standard reference (Aspirin).

Acetic acid-induced writhing model produces pain sensation by triggering inflammatory response and such pain stimulus leads to release of Arachidonic acid from tissue [19]. The analgesic effect of A. zygia may be mediated through peripheral pain mechanism and/or through suppression of prostaglandin pathway. Any agent that demonstrates analgesia by decreasing the number of writhings will preferably act by inhibition of prostaglandin synthesis [20].

In the hot plate model, the paws of mice are very sensitive to temperatures at $50-55 \pm 1{ }^{\circ} \mathrm{C}[10]$. Increase in pain reaction time (PRT) or latency period indicates the level of analgesia of drug or extract [21]. In comparing PRT at the pre and post treatments, the extract at 20,40 and $80 \mathrm{mg} / \mathrm{kg}$ increased the pain reaction time $(\mathrm{p}<0.05)$ in a dose-dependent manner. The hot plate model has been used to study centrally acting analgesic [22]. In this model, sensory nerves sensitize the nociceptors and the involvement of endogenous substances such as prostaglandins are minimized.

Toxicological studies for all herbal medicines including the determination of their median lethal dose (LD 50) and other such parameters essential for a proper dosage are desirable and necessary. If there is the suspected need for more detailed studies, such herbal medicines may be subjected to sub-acute tests. The general purpose of the sub-acute toxicity tests is to determine the organs that are likely to be susceptible to toxicity by the herbal medicines [23]. Histopathological effects of the administration of $250 \mathrm{mg} / \mathrm{kg}$ and $500 \mathrm{mg} / \mathrm{kg}$ per day of the aqueous methanol extracts of A. zygia to rats showed no evidence of tissue necrosis on the liver, kidney, heart and spleen. There were no marked adverse alterations or degeneration of tissues since these vital organs showed normal architectures suggesting no morphological disruptions as compared with the control group. It is an indication of the low toxicity of the extract [11], therefore $A$. zygia could be said to be relatively safe.

\section{Conclusion}

On the basis of the results obtained from our investigations, it could be said that Albizia zygia possesses analgesic activities and can be considered safe on acute basis. The results from this study thus support the claimed traditional use of A. zygia in the management of waist pain, sprain, arthritis and in feverish conditions.

\section{References}

[1] http: //www.world agroforestry centre.org/sea/products/AFD bases/AF/index.asp.

[2] Arbonnier M. Trees, Shrubs and Lianas of West Africa dry zones. $2^{\text {nd }}$ edition. Margaraf Publishers, $2004: 221$.

[3] Mbaya AW and Ibrahim UI. In vivo and in vitro activities of medicinal plants on Haemic and Humoral Trypanosomes. International Journal of Pharmacy 2011, 7(1): 1-11.

[4] National Institute of Health. 2002. Public health service policy on humane care and use of laboratory animals. Office of the laboratory animal welfare, USA. 1-19.

[5] Brain K.R. and Turner T.D. Practical evaluation of Phytopharmaceuticals. $1^{\text {st }}$ ed. Wright-Scientechnica, Bristol; $1975: 144$.

[6] Ciulei I. Methodology for analysis of vegetable drugs. United Nations Industrial Development Organisation. Romania; 1981: 17-25.

[7] Evans W.C. Trease and Evans Pharmacognosy. 15 ${ }^{\text {th }}$ ed. WB Saunders, Toronto; 2006: 95-99, 512, 545-547.

[8] Harborne J.B. Phytochemical methods. A guide to modern technique of plant analysis. $1^{\text {st }}$ ed. Chapman and Hill, London; 1992 : 279.

[9] Dambisya YM and Lee S. Influence of Temperature, $\mathrm{Ph}$ and Naloxone on the anti-nociceptive activity of Chana striatus (Haraun) extract in mice. Journal of Ethnopharmacology 1999, 66: 181-186.

[10] Franzotti EM, Santos CVF, Rodrigues HMS, Mourao RHV, Andrade MR, Antoniolli AR. Anti-inflammatory, analgesic and acute toxicity of Sida cordifolia L. Journal of Ethnopharmacology 2000, 72: 273-277.

[11] Dietrich L. A new approach to practical acute toxicity testing. Archives of Toxicology 1983, 54: $275-287$.

[12] Abere TA and Agoreyo FO. Antimicrobial and toxicological evaluation of the leaves of Baissea axillaries Hua used in the management of HIV/AIDS Patients. BMC Complementary and Alternative Medicine 2006, 6: 22.

[13] Ahmadiani A, Hosseiny J, Semnanian S, Javan M, Saccdi F, Kamalinejad M and Sareni S. Anti-nociceptive and anti-inflammatory effect of Eleagy angustifolia fruit extract. Journal of Ethnopharmacology 2000, 61: 287-292.

[14] Manthey JA. Biological properties of flavor pertaining to inflammation. Microcircult 2000, 7: 29-34.

[15] Rang HP, Dale MM, Ritter JM and Moore PK. Pharmacology. $5^{\text {th }}$ edition, Elsevier Science Ltd, New Delhi, India 2003, 562-569.

[16] Raquibul SM, Hossain MM, Aktar R, Jamila M, Mazumder MEH, Alam MA, Faruque A, Rame S and Rahman S. Analgesic activity of the different fractions of the aerial parts of Commenila benghalensis Linn. International Journal of Pharmacology 2010 , 6(1): 63-67.

[17] Onasanwo SA and Elegbe RA. Antinociceptive and anti-inflammatory properties of the leaf extract of Hedranthera barteri in rats and mice. African Journal of Biomedical Research 2008, 2: 109-118.

[18] Machioro M, Blank MFA, Moura RHV and Antioniolli. Anti-nociceptive activity of the aqueous extract of Erythrine velutina leaves. Fitoterapia 2005, 76: 637-642.

[19] Ahmed F, Hossain MH, Rahman AA and Shahid TZ. Anti-nociceptive and sedative effects of the bark of Cerbera odollam. Journal of Oriental Pharmacy Exp. Med., 2006, 6: 344-348.

[20] Ferdus M, Rouf R, Shilpi JA and Uddin SJ. Anti-nociceptive activity of the ethanolic extract of Ficus racemosa Linn. Journal of Oriental Pharmacy Exp. Med., 2008, 8: 93-96.

[21] Ramadran K and Bainath LA. Critical analysis of the experimental evaluation of nociceptive reactions in animals. Pharm. Research 1986, 3: 253-270.

[22] www. World agroforestry centerorg/sea/product. Accessed 03/09/2013.

[23] Abere TA, Okoto PE and Agoreyo FO. Antidiarrhoea and toxicological evaluation of the leaf extract of Dissotis rotundifolia Triana (Melastomataceae). BMC Complementary and Alternative Medicine 2010, 10: 71. 